\title{
The impact of knowledge sharing on innovative work behavior of Vietnam telecommuni- cations enterprises employees
}

\author{
Thi Phuong Linh Nguyen a*, Nhat Minh Trana, Xuan Hau Doan a and Van Hau Nguyen ${ }^{a}$
}

${ }^{a}$ National Economics University, Vietnam

\begin{tabular}{l}
\hline C H R O N I C L E \\
\hline Article history: \\
Received: July 82019 \\
Received in revised format: July 9 \\
2019 \\
Accepted: August 11, 2019 \\
Available online: \\
August 12, 2019 \\
\hline Keywords: \\
Knowledge sharing \\
Knowledge donation \\
Knowledge collection \\
Innovative work behavior \\
\hline
\end{tabular}

\section{A B S T R A C T}

Innovative work behavior can stem from the sharing of knowledge between individuals and colleagues. Based on sample size survey of 396 Vietnam telecommunication employees with Cronbach's Alpha analysis, exploratory factor analysis (EFA), correlation analysis, regression analysis, the study shows that the impact of knowledge sharing with two central processes (knowledge donation and knowledge collection) on innovative work behavior was meaningful. Compared with the process of knowledge donation, the process of knowledge collection has a stronger impact on innovative work behavior $(\beta=0.213$ and 0.204 respectively). Besides, the authors propose some suggestions for telecommunications enterprise managers to influence the employee's behavioral innovation through the impact of knowledge sharing.

(C) 2020 by the authors; licensee Growing Science, Canada

\section{Introduction}

In the service sector, the telecommunications service with the role of social infrastructure has the effect of promoting the process of economic growth and social restructuring towards progress, productivity and effective improvement in rural agriculture, industry and social services to improve the quality of life. The level of competition in Vietnam's telecommunications market is forecasted to be even more intense as the market has entered a saturation phase and more new service providers have appeared on the market as entering world trade organization (WTO). Besides, with the pervasive nature of the industrial revolution 4.0, the development of technology will be faster and stronger with remarkable changes. Therefore, Vietnam telecommunications enterprises need to focus on developing in depth, proactively promote innovation, exploit knowledge and develop technology to catch up with the continuous progress of technology and effectively capture the great opportunities that this revolution brings. From the early 1990s, researchers and business managers around the world have adopted and approached a new trend in enterprise development: Knowledge Management. It is understood as a process that consists of basic activities such as creating, acquiring, storing, exploiting, sharing and developing the source of knowledge assets in the enterprise into useful values for the operation of enterprise. In those activities, knowledge sharing is considered a core activity of knowledge management. Knowledge sharing among employees and departments within the organization is necessary to transfer the knowledge of individuals and groups into * Corresponding author.

E-mail address: plinhkt@gmail.com (T. P. L. Nguyen)

C 2020 by the authors; licensee Growing Science, Canada doi: $10.5267 /$ j.msl.2019.8.016 
organizational knowledge, leading to effective knowledge management. Some researchers found that knowledge sharing is critical for the success of a company (Davenport \& Prusak, 1998), when individuals share knowledge with each other, it significantly increases the resources of an organization, reducing the time wasted in testing and reporting errors, as long as knowledge sharing is reluctant to affect the organization's existence (Lin, 2007). When employees actively share knowledge, knowledge is acquired and thereby facilitating conditions to promote innovative work behavior - the basis of proposing and realizing ideas in the implementation of work at organization. Therefore, learning about knowledge sharing and the impact of knowledge sharing on innovative work behavior is really necessary.

\section{Research model and hypotheses}

\subsection{Knowledge sharing}

Knowledge sharing involves different individuals at various levels in the organization; sharing between individuals or between individuals and a group of people. This process assumes that at least two parties are involved: one communicates or distributes knowledge while the other acquires and collects knowledge (Van den Hooff \& de Ridder, 2004; Vithessonthi, 2008). Weggeman (2000) and Van der Rijt (2002) studied the difference between these two processes, in which: donating knowledge is shared with others the intellectual capital of the owner himself; collecting knowledge is to consult with colleagues to share their own intellectual capital. Van den Hooff and de Ridder (2004) defined knowledge sharing as the process by which individuals exchange knowledge (both tacit and explicit knowledge) and create new knowledge together. Van den Hooff and de Ridder (2004) separated knowledge sharing into two processes of donating and collecting knowledge when individuals exchange knowledge with each other. This view was inherited by Van den Hooff and de Ridder (2004) from the previous three studies of Weggeman (2000) that distinguished between donors and recipients in the process of knowledge sharing; Oldenkamp (2001) discussed how knowledge sharing relates to people with knowledge owners and recipients, wanting to learn knowledge; Ardichvili et al. (2003) with the view that knowledge sharing includes the provision of new knowledge and the need for new knowledge. Some recent studies also inherit the research of scholars before the concept of knowledge sharing consists of two central processes of knowledge donation and collection. In this study, the authors also mentioned knowledge sharing including two processes of donating and collecting knowledge as the views of some scholars mentioned above.

\subsection{Innovative work behavior}

Innovative work behavior is defined as the behavior of employees to create, introduce and apply new ideas intentionally at work, a group or an organization that contributes to performance (Janssen, 2000). This behavior is intentional behavior of individuals to create and implement new and useful ideas to benefit individuals, groups or organizations (Bos-Nehles \& Veenendaal, 2017). It is also a process for creating new problem-solving applications that begin with problem identification, finding solutions and implementing organizational solutions (Turgut \& Beğenirbaş, 2013). Åmo and Kolvereid (2005) defined innovative work behavior as the ability to actively work to produce new products, find new markets, new processes and new combinations (Dhar, 2015). Innovative work behavior is divided into two phases by Dorenbosch et al. (2005): inventing and implementing ideas; meanwhile Scott and Bruce (1994) divided into three phases: forming new and useful ideas, seeking support and implementing ideas that were formed and promoted. The first stage is conceptualization - employees identify problems and opportunities, seeking new ideas to act as solutions to problem solving; the second stage is called idea protection - the idea is promoted throughout the organization to seek support for the next development or in other words, group building, including individuals with the capacity needed to practice ideas; the third stage is idea practice - putting ideas into the promotion of daily business or organization work (Janssen, 2000).

\subsection{The impact of knowledge sharing on innovative work behavior}

Knowledge sharing is one of the important processes of knowledge management systems (Bartol \& Srivasta, 2002) since this is a way to transparent tacit knowledge and is the foundation for creating new knowledge. Vorakulpipat and Rezgui (2008) pointed out that the stage of knowledge creation is the next 
step and involves the need for innovation. The process of creating knowledge takes place through the transition process, which is the process by which one expresses and shares with others. People with limited knowledge of some aspects will then capture knowledge from others. King (2009) described the process of socialization and externalization in knowledge creation theory as social processes that allow people to interact and share knowledge, thereby creating new knowledge. According to Darroch and McNaughton (2002), strengthening the sharing of knowledge by organizations leads to creativity and innovation to develop new working methods, new procedures and change traditional methods as well as make organizations grow and operate better. Knowledge sharing is an important factor affecting the company's innovation (Qammach, 2016). Explicit knowledge directly affects the rate of innovation while tacit knowledge affects innovation quality.

Knowledge sharing is a factor that encourages individuals to create knowledge and transform it into greater power (Liebowitz \& Chen, 2001). When employees actively share knowledge, knowledge is acquired and facilitate conditions to promote innovative work behavior. Holub (2003) emphasized that the transfer of knowledge will be faster through sharing that fosters thinking and creativity. Processes in the SECI model: socialization, externalization, combination, and internalization are identified as useful for the creation and exchange of knowledge (Nonaka \& Takeuchi, 1995). Knowledge sharing is capable of promoting the creation and implementation of ideas of knowledge recipients (Mura et al., 2013). Sharing knowledge with colleagues allows individuals to exchange ideas, discuss ideas with peers, draw their attention to the benefits of ideas and implement ideas by turning into a viable solution (Mura et al, 2016). Wang and Noe (2010) emphasized that individuals involved in knowledge sharing have the expectation that their ideas will be approved in the future by colleagues in the form of promoting or implementing new ideas. These individuals trust that their managers and colleagues are more satisfied with their work (Li, 2010). Sharing knowledge among employees makes them more responsive in situations (Hon \& Rensvold, 2006), thus more creative. Thus, knowledge sharing is related to innovation in enterprises. Innovative work behavior can stem from the sharing of knowledge between individuals and colleagues. Previous researchers such as Radaelli et al. (2014), Akhavan et al. (2015), Jaberi (2016), Phung et al. (2017), Akram et al. (2018) have confirmed that having an impact of donating and collecting knowledge on innovative work behavior. Therefore, the hypotheses are proposed as follows:

Hypothesis 1 (H1): The process of donating knowledge has a positive impact on innovative work behavior. Hypothesis 2 (H2): The process of collecting knowledge has a positive effect on innovative work behavior.

\section{Knowledge sharing}

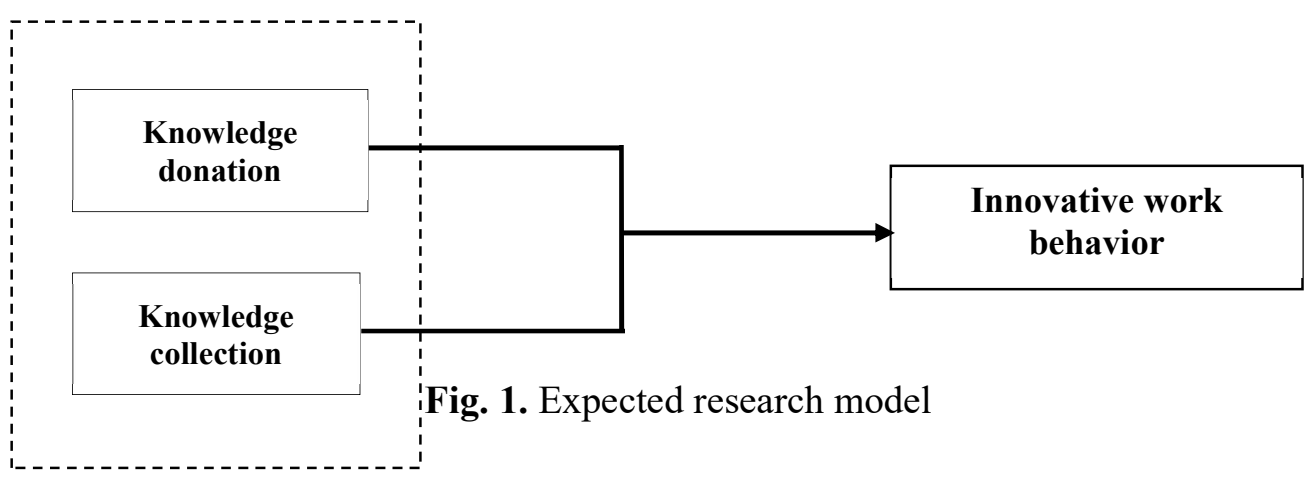

\section{Research methodology}

\section{Data collection}

The study used a combination of qualitative and quantitative methods, in which:

After conducting the research on secondary data, the authors conducted in-depth interviews with 2 groups of subjects (i) telecommunications enterprise managers (heads/deputy heads of board in telecommunications enterprises); (ii) telecommunications enterprise employees to understand and clarify 
knowledge sharing and the impact of knowledge sharing on innovative work behavior of telecommunications enterprise employees. Based on the research overview and the results of in-depth interviews, the authors conducted a survey to serve the investigation. There are 3 scales in the research model with items that are inherited from previous studies. The sample of the authors is the employee currently working in telecommunications enterprises in the North, Central and South, specifically the authors have conducted a total investigation of 30 telecommunications enterprises across the country, accounting for about $40 \%$ of the total number of telecommunications service providers currently doing business. Their positions in departments are much related to knowledge sharing such as: Centre of Information Technology/Operations, Department of Planning, Department of Labor Organization/Human Resources, Department of Research and Development Products/Network, Department of Technical, Department of Quality Management, Department of Project Management and other functional departments. The authors chose samples in a convenient way and to ensure representativeness, the research sample tried to be distributed according to the North, Central and South regions. In addition, the selection of the research sample appropriately allocated according to job position and demographic factors to ensure comparison in the results obtained. The authors investigated through sending the survey directly and via the Internet (email, social networks and forums) thanks to google docs or surveymokey tool to study subjects. After cleaning the data, the number of official observations collected is 396 to perform the next analysis steps.

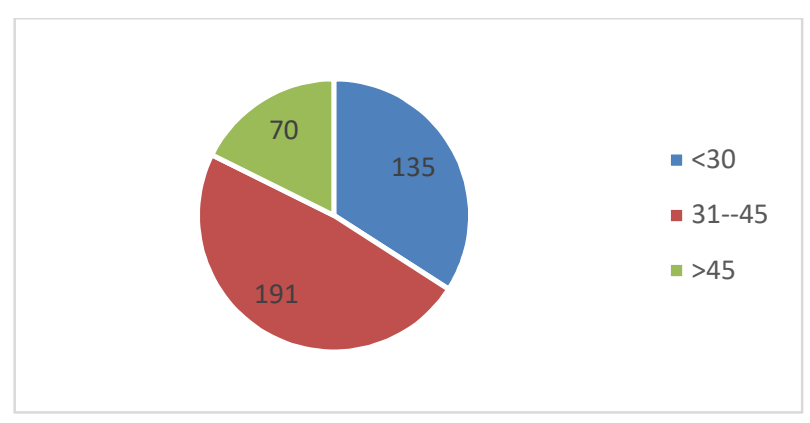

Age

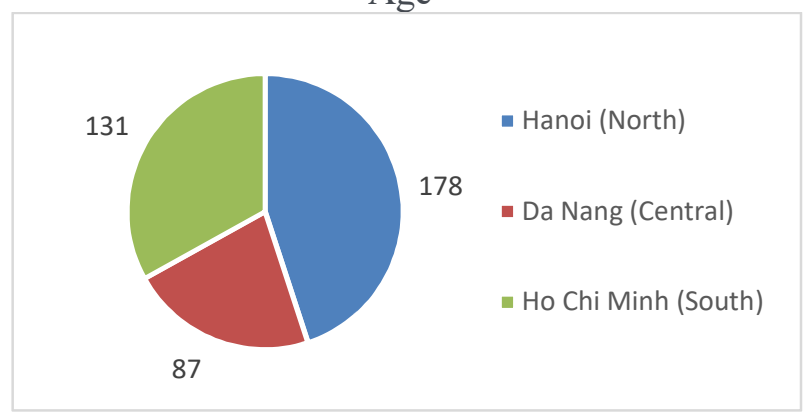

Working region

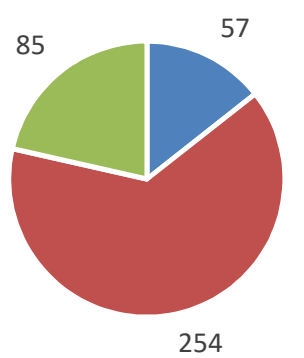

- Intermediate

- Bachelor

- Master or doctor
Educational background

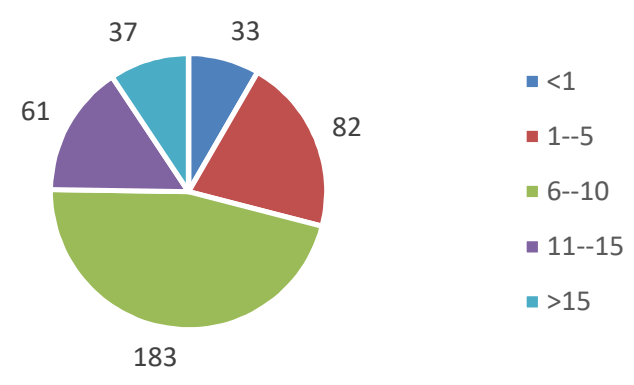

Years of Job experience

Fig. 2. Personal characteristics of the participants

Statistics 396 observed in the official quantitative research shows that the sample of Vietnam telecommunications enterprises employees is mainly male (accounting for 61.4\%); most of them are in the age group from 31 to 45 (accounting for 48.2\%), then to the age group from 20 to 30 (accounting for 34.1\%); educational qualification of the surveyed employees has mainly graduated bachelor (accounting for $64.1 \%$ ); the number of employees with 6 to 10 years of working experience accounts for nearly half of the total number of observations, namely $46.2 \%$; followed by 1 to 5 years, accounting for $20.7 \%$. In addition, observations are still more distribution in the North than in the South and in the Central, with $44.9 \% ; 33.1 \% ; 22.0 \%$ respectively.

\section{Measures}

The scales are drawn from the research overview, with adjustments based on the results of in-depth interviews. Each scale is measured by a number of observations used by scholars in their research. The observed variables and scales are used from foreign studies, translated from English into Vietnamese and 
then translated back from Vietnamese into English. After completing the translation of the scale sets, the authors have consulted the opinions of some experts and employees of telecommunications enterprises (who directly answer) to ensure compliance; at the same time, the observed variables and scales are translated accurately. Knowledge sharing is described by two processes of knowledge donation (4 observations), the process of knowledge collection (4 observations). Each scale is described by 4 proven and verified observations by De Vries et al. (2006); Tohidinia and Mosakhani (2010). Variables are measured by Likert scale from 1 (totally disagree) to 5 (totally agree). Innovative work behavior is described by 4 observations which are entirely inherited from studies by Scott and Bruce (1994); Janssen (2000); Bysted (2013). Variables are measured by Likert scale from 1 (totally disagree) to 5 (totally agree).

\section{Research results}

\section{Verify Cronbach's Alpha reliability}

The reliability of the scale is assessed through the Cronbach's Alpha coefficient. Using Cronbach's Alpha reliability coefficient method before analyzing the exploratory factor (EFA) to eliminate unsuitable observed variables due to these observed variables (garbage variable) can create false elements (Nguyễn \& Nguyễn, 2009). According to Hoàng and Chu (2008), Cronbach's Alpha coefficient from 0.8 to nearly 1 is good measurement scale; 0.7 to 0.8 is usable; 0.6 or more can also be used in case the measurement concept is new or new to the respondents in the new research context. In addition, when evaluating scales, the correlation coefficient (corrected item-total correlation) must be 0.3 or higher to ensure the requirement (Hair et al., 2010).

\section{Table 1}

Cronbach's Alpha test results of knowledge donation process

\begin{tabular}{crrrr}
\hline \multicolumn{5}{c}{ Cronbach's Alpha $=\mathbf{0 . 7 9 0}$} \\
\hline & $\begin{array}{c}\text { Scale Mean if Item } \\
\text { Deleted }\end{array}$ & $\begin{array}{c}\text { Scale Variance if } \\
\text { Item Deleted }\end{array}$ & $\begin{array}{c}\text { Corrected Item-Total } \\
\text { Correlation }\end{array}$ & $\begin{array}{c}\text { Cronbach's Alpha if } \\
\text { Item Deleted }\end{array}$ \\
\hline Do1 & 10.88 & 3.625 & 0.678 & 0.710 \\
Do2 & 10.86 & 3.115 & 0.578 & 0.760 \\
Do3 & 10.93 & 3.399 & 0.557 & 0.762 \\
Do4 & 10.82 & 3.642 & 0.631 & 0.728 \\
\hline
\end{tabular}

Cronbach's Alpha coefficients calculated for the 4 observations of the knowledge donation process scale are $0.790>0.7$ (Table 2). Thus, it can be said that the scale is suitable to measure the process of knowledge donation, the correlation coefficient of variables - the total for each observed variable is greater than 0.4 and Cronbach's Alpha coefficient if removed each the observed variable is smaller than 0.790 so all observed variables can be retained to measure the scale of knowledge donation process.

\section{Table 2}

Cronbach's Alpha test results of knowledge collection process

\begin{tabular}{ccccc}
\hline \multicolumn{5}{c}{ Cronbach's Alpha $=\mathbf{0 . 8 0 9}$} \\
\hline & $\begin{array}{c}\text { Scale Mean if Item } \\
\text { Deleted }\end{array}$ & $\begin{array}{c}\text { Scale Variance if } \\
\text { Item Deleted }\end{array}$ & $\begin{array}{c}\text { Corrected Item-Total } \\
\text { Correlation }\end{array}$ & $\begin{array}{c}\text { Cronbach's Alpha if } \\
\text { Item Deleted }\end{array}$ \\
\hline Co1 & 9.45 & 5.652 & 0.527 & 0.805 \\
Co2 & 9.45 & 4.731 & 0.774 & 0.688 \\
Co3 & 9.23 & 5.073 & 0.670 & 0.740 \\
Co4 & 9.38 & 5.193 & 0.551 & 0.800 \\
\hline
\end{tabular}

With the scale of knowledge collection process, when running SPSS, Cronbach's Alpha coefficient is 0.809 greater than 0.7 (Table 2). Thus, it can be said that the scale is suitable for measurement. The correlation coefficients of variables - total for each observed variable are greater than 0.4 , so the observed variables can be retained to measure the factor of collection process. The value of Cronbach's Alpha if removed each the observed variable is smaller than Cronbach's Alpha of the scale is 0.809. Therefore, the scale of factor of knowledge collection process will include the above 4 variables. 
Table 3

Cronbach's Alpha test results of innovative work behavior

\begin{tabular}{ccccc}
\hline \multicolumn{5}{c}{ Cronbach's Alpha $=\mathbf{0 . 8 0 8}$} \\
\hline & $\begin{array}{c}\text { Scale Mean if Item } \\
\text { Deleted }\end{array}$ & $\begin{array}{c}\text { Scale Variance if } \\
\text { Item Deleted }\end{array}$ & $\begin{array}{c}\text { Corrected Item-Total } \\
\text { Correlation }\end{array}$ & $\begin{array}{c}\text { Cronbach's Alpha if } \\
\text { Item Deleted }\end{array}$ \\
\hline In1 & 11.50 & 2.979 & 0.599 & 0.772 \\
In2 & 11.59 & 2.813 & 0.608 & 0.769 \\
In3 & 11.57 & 2.843 & 0.671 & 0.738 \\
In4 & 11.42 & 2.920 & 0.623 & 0.761 \\
\hline
\end{tabular}

Cronbach's Alpha coefficients calculated for the 4 observations of the innovative work behavior scale are 0.808 which is greater than 0.7 (Table 3). Thus, it can be said that the scale is suitable to measure innovative work behavior, the correlation coefficient of variables - the total for each observed variable is greater than 0.4 and the Cronbach's Alpha coefficient if eliminating each observed variable is less than 0.808 so all observed variables can be retained to measure the scale of innovative work behavior.

\section{Exploratory factor analysis}

The Exploratory Factor Analysis (EFA) method helps the researchers evaluate two important values of the scale: convergence value and discriminant value. The EFA factor analysis method is interdependence techniques, which means that there are no independent variables and variables that rely on correlation between variables. EFA is used to abbreviate a set of $k$ observation variables into a set $\mathrm{F}(\mathrm{F}<\mathrm{k})$ of more meaningful factors. The basis of this reduction is based on the linear relationship of the elements to the original variables (observed variables). Thus, an EFA was deemed significant as the appropriate analytical step to examine the factor structure of the scale. To confirm that this study data set is correct for factor analysis, the authors assessed whether the Kaiser-Meyer-Olkin (KMO) measure of sampling adequacy value was 0.6 or above and determined that the Barlett's test of sphericity value was significant (i.e.: 0.5 or less). All indicators here were guaranteed.

\section{Table 4}

KMO and Bartlett's Test

\begin{tabular}{lcc}
\hline & KMO and Bartlett's Test & \\
\hline Kaiser-Meyer-Olkin Measure of Sampling Adequacy. & & .752 \\
Bartlett's Test of Sphericity & Approx. Chi-Square & 2080.707 \\
& df & 66 \\
Sig. & .000 & \\
\hline
\end{tabular}

To define how many factors to retain, a number of issues were considered. Using Kaiser's criterion, factors with an eigenvalue greater than one are suitable. All three components recorded eigenvalues above 1. These three components explain 73.083 percent of variance. This information is in Table 5 .

\section{Table 5}

Total variance explained

\begin{tabular}{|c|c|c|c|c|c|c|}
\hline \multirow{2}{*}{ Component } & \multicolumn{3}{|c|}{ Extraction Sums of Sauared Loadings } & \multicolumn{3}{|c|}{ Rotation Sums of Sauared Loadings } \\
\hline & Total & $\%$ of Variance & Cumulative $(\%)$ & Total & $\%$ of Variance & Cumulative $(\%)$ \\
\hline 1 & 3.702 & 30.850 & 30.850 & 3.608 & 30.068 & 30.068 \\
\hline 2 & 3.338 & 27.815 & 58.665 & 2.582 & 21.518 & 51.585 \\
\hline 3 & 1.730 & 14.418 & 73.083 & 2.580 & 21.498 & 73.083 \\
\hline 4 & .737 & 6.144 & 79.227 & & & \\
\hline 5 & 657 & 5.474 & 84.701 & & & \\
\hline 6 & .510 & 4.246 & 88.947 & & & \\
\hline 7 & .413 & 3.438 & 92.385 & & & \\
\hline 8 & .287 & 2.390 & 94.775 & & & \\
\hline 9 & .281 & 2.345 & 97.120 & & & \\
\hline 10 & .233 & 1.939 & 99.059 & & & \\
\hline 11 & .088 & .734 & 99.793 & & & \\
\hline 12 & .025 & .207 & 100.000 & & & \\
\hline
\end{tabular}

The results of EFA analysis are shown in Table 6 . As a result, the 12 observed variables were grouped 
into 3 scales: knowledge donation, knowledge collection and innovative work behavior.

Table 6

Rotated Component Matrix

\begin{tabular}{llcl}
\hline & & Component & \\
\cline { 2 - 4 } do4 & 1 & 2 & 3 \\
\hline do1 & .956 & & \\
do3 & .955 & & \\
do2 & .954 & & \\
in3 & .917 & .796 & .884 \\
in2 & & .792 & .797 \\
in1 & & .785 & .752 \\
in4 & & .764 & .708 \\
\hline co2 & & & \\
\hline co3 & & & \\
co1 & & & \\
co4 & & & \\
\hline Correlation analysis & & & \\
\hline
\end{tabular}

After conducting EFA analysis, the next step is to conduct correlation analysis. Pearson correlation coefficient measures the degree of linear correlation between two variables. In principle, the Pearson correlation will find a straight line that best fits the linear relationship of the two variables.

Table 7

Results of correlation analysis

\begin{tabular}{llccc}
\hline & & Knowledge donation & Knowledge collection & Innovative work behavior \\
\hline Knowledge donation & Pearson Correlation & 1 & $.427^{* *}$ & $.300^{* *}$ \\
& Sig. (2-tailed) & & .000 & .000 \\
& $\mathrm{~N}$ & 396 & 396 & 396 \\
\hline Knowledge collection & Pearson Correlation & $.427^{* *}$ & 1 & $.295^{* *}$ \\
& Sig. (2-tailed) & .000 & .000 & 396 \\
& $\mathrm{~N}$ & 396 & 396 & 1 \\
\hline Innovative work behavior & Pearson Correlation & $.300^{* *}$ & $.295^{* *}$ & 396 \\
& Sig. (2-tailed) & .000 & .000 & 396 \\
\hline
\end{tabular}

**. Correlation is significant at the 0.01 level (2-tailed).

All sig. $<0.05$ show that the correlation coefficient $r$ is statistically significant. This proves that the scale in the study is correlated with each other and is positively correlated $(r>0)$, ensuring the conditions for conducting linear regression analysis in the next step.

\section{Linear regression analysis}

Initial research hypotheses should also use regression analysis to test. Regression analysis will determine the role of knowledge donation and collection in influencing innovative work behavior. In addition, to evaluate the appropriateness of the model, the authors used the coefficient of determination $\mathrm{R}^{2}$ (Rsquare). When examining the correlation phenomenon, the study uses Durbin-Watson coefficient with condition that Durbin-Watson $<3$. The standardized Beta coefficient is used to evaluate the importance of each component, the higher the standardized beta coefficient of a component, the greater the impact of that scale on the innovative work behavior.

\section{Table 8}

Test significance of the regression model

\begin{tabular}{cccccc}
\hline Model & $\mathrm{R}$ & $\mathrm{R}$ Square & Adjusted R Square & Std. Error of the Estimate & Durbin-Watson \\
\hline 1 & $.352^{\mathrm{a}}$ & .124 & .120 & .96015 & 1.684 \\
\hline
\end{tabular}

a. Predictors: (Constant), Knowledge donation, Knowledge collection

b. Dependent Variable: Innovative work behavior

The R square value in the model summary depicts the degree to which the independent variables explain the variation in innovative work behavior. From Table 8, it can be observed that the $\mathrm{R}$ square value is 0.124 , which indicates that knowledge donation and knowledge collection accounts 12.4 per cent of innovative work behavior among employees of Vietnam telecommunication enterprises. 
Table 9

$\underline{\text { Regression results for the impact of knowledge donation, knowledge collection on innovative work behavior }}$

\begin{tabular}{|c|c|c|c|c|c|c|}
\hline \multirow{2}{*}{\multicolumn{2}{|c|}{ Model }} & \multicolumn{2}{|c|}{ Unstandardized Coefficients } & \multicolumn{2}{|c|}{ Standardized Coefficients } & \multirow[b]{2}{*}{ Sig. } \\
\hline & & $\mathrm{B}$ & Std. Error & Beta & $\mathrm{t}$ & \\
\hline \multirow[t]{3}{*}{1} & (Constant) & 1.893 & .210 & & 8.994 & .000 \\
\hline & Knowledge donation & .258 & .066 & .204 & 3.897 & .000 \\
\hline & Knowledge collection & .288 & .071 & .213 & 4.085 & .000 \\
\hline
\end{tabular}

a. Dependent Variable: Innovative work behavior

The estimated model indicates the extent to which each of knowledge donation and collection influences innovative work behavior. From Table 9 we can observe that both the knowledge donation and knowledge collection had positive impacts on innovative work behavior $(\beta=0.204$ and $\beta=0.213$, sig $=.000)$. All hypotheses are accepted.

\section{Discussion and implication}

The impact of knowledge sharing on innovative work behavior is explored in many studies. Some studies acknowledge that this relationship can be mentioned as research by Radaelli et al. (2014), Akhavan et al. (2015), Jaberi (2016), Phung et al. (2017), Akram et al. (2018). In research at telecommunications enterprises, the authors also concluded that knowledge sharing with two central processes is knowledge donation and collection related to innovative work behavior. From the results of formal quantitative research, we see that the impact of knowledge sharing on innovation behavior is meaningful. Compared with the process of knowledge donation, the process of knowledge collection has a stronger impact on innovative work behavior ( $\beta=0.213$ and 0.204 respectively). This result is explained based on the results of the interview with telecommunications enterprise employees. When interviewing, the authors found that employees who actively communicate and acquire knowledge are often quite proactive in interacting with colleagues to create new ideas to apply to work. An employee with 6 - 10 years of experience answered: "I often have a habit of talking to colleagues and willing to tell colleagues what I know. I think that will give us the opportunity to discuss and find new ways to work more effectively". A head of board with more than 15 years of experience answered: "I see employees who actively communicate and share their knowledge with colleagues often actively engage with colleagues, establish innovation groups in the enterprise. Many initiatives come from these groups; therefore, I think should encourage such groups because a person is not easy to find new solutions that are useful for the enterprise"

An employee with 1 - 5 years of experience answered: "I have not been in this company for a long time yet, so when I was assigned by the boss, the first thing I thought about was to consult with an experienced colleague. I am not afraid to argue with my colleagues to find new data processing methods, how to manage new files or the idea of upgrading the intranet system".

A head of board with 6 - 10 years of experience answered: "I always encourage employees to learn from colleagues and myself. In the management position, when the employee proposed the idea, I was willing to give ideas so that the idea could be quickly deployed and effectively applied to the practical work".

The results of qualitative and quantitative research show that knowledge sharing consists of two central processes of donating and collecting knowledge that are related to innovative working behaviors. Therefore, the managers need to make proposals to enhance knowledge sharing so that the impact on the innovative work behavior is made. The results of interviews with telecommunications enterprise employee show that some answers directly addressed innovative work behavior. An employee with 6 - 10 years of experience answered: "If there is no measure, employees like me always want to do it the old way, do not want to change or improve at work. In the enterprise I am doing, it is difficult to give my opinion to senior leaders, so I think there must be appropriate measures to change our way of thinking and how we have been doing for years"

A head of board with more than 15 years of experience answered: "I often use brainstorming methods for employees to think and give ideas and suggestions at work. The important thing is how to apply the ideas and suggestions of the employees, who will be the ones who do it because if not applied, all ideas and suggestions will only be on paper forever". 
Therefore, the authors proposed some suggestions for telecommunications enterprise managers to influence the employee's behavioral innovation:

Firstly, applying Kaizen method in management. Managers should encourage employees to come up with new ideas and suggestions through suggestion boxes, software systems, social networks, etc. After that, evaluating each new idea and proposal effectively to choose new ideas and feasible proposals for applying to work practices. Kaizen method will apply successfully only when both Vietnamese telecommunications enterprise managers and employees have innovative and modern thinking, not accepting the traditional methods.

Secondly, organizing seminars periodically with the participation of managers and employees in each department. At the seminar, each employee must comment on his/her current work and discuss plans, development strategies, work processes, new products/services. After the seminar, feasible ideas will be assigned to the proponent and some colleagues to implement.

Thirdly, taking the time and resources to test and implement new ideas. The work of Vietnamese telecommunications enterprise employees mostly has to run according to the set plan and schedule, so in many cases they are forced to use traditional methods to deploy. New ideas when applied are not always successful right from the first time so we need to plan, assign tasks and spend time for testing.

\section{Acknowledgement}

This research is funded by National Economics University, Hanoi, Vietnam

\section{References}

Åmo, B. W., \& Kolvereid, L. (2005). Organizational strategy, individual personality and innovation behavior. Journal of Enterprising Culture, 13(01), 7-19.

Akram, T., Lei, S., Haider, M. J., \& Hussain, S. T. (2018). Exploring the impact of knowledge sharing on the innovative work behavior of employees: A study in China. International Business Research, 11(3), 186194.

Akhavan, P., Hosseini, S. M., Abbasi, M., \& Manteghi, M. (2015). Knowledge-sharing determinants, behaviors, and innovative work behaviors: An integrated theoretical view and empirical examination. Aslib Journal of Information Management, 67(5), 562-591.

Ardichvili, A., Page, V., \& Wentling, T. (2003). Motivation and barriers to participation in virtual knowledgesharing communities of practice. Journal of Knowledge Management, 7(1), 64-77.

Bartol, K. M., \& Srivastava, A. (2002). Encouraging knowledge sharing: The role of organizational reward systems. Journal of Leadership \& Organizational Studies, 9(1), 64-76.

Bos-Nehles, A. C., \& Veenendaal, A. A. (2017). Perceptions of HR practices and innovative work behavior: the moderating effect of an innovative climate. The International Journal of Human Resource Management, 1-23.

Bysted, R. (2013). Innovative employee behaviour: the moderating effects of mental involvement and job satisfaction on contextual variables. European Journal of Innovation Management, 16(3), 268-284.

Darroch, J., \& McNaughton, R. (2002). Examining the link between knowledge management practices and types of innovation. Journal of Intellectual Capital, 3(3), 210-222.

Davenport, T. H., \& Prusak, L. (1998). Working knowledge: How organizations manage what they know. Harvard Business Press.

De Vries, R. E., Van den Hooff, B., \& de Ridder, J. A. (2006). Explaining knowledge sharing: The role of team communication styles, job satisfaction, and performance beliefs. Communication research, 33(2), $115-135$.

Dorenbosch, L., Engen, M. L. V., \& Verhagen, M. (2005). On-the-job innovation: The impact of job design and human resource management through production ownership. Creativity and innovation management, 14(2), 129-141.

Hair, J. F., Black, W. C., Babin, B. J., Anderson, R. E., \& Tatham, R. L. (2010). Multivariate data analysis (Vol. 7).

Hoàng, T., \& Chu, N. M. N. (2008). Phân tích dữ liệu nghiên cứu với SPSS-tập 1.

Holub, S. F. (2003). Knowledge sharing is a change-management exercise. Tax Practice Management, 34(6), 
361-363.

Jaberi, E. (2016). The effect of knowledge sharing on innovative behavior among employee of Besat hospital in city of Hamedan. International Academic Journal of Accounting and Financial Management, 3(4), 4147.

Janssen, O. (2000). Job demands, perceptions of effort-reward fairness and innovative work behaviour. Journal of Occupational and organizational psychology, 73(3), 287-302.

Li, W. (2010). Virtual knowledge sharing in a cross-cultural context. Journal of Knowledge Management, 14(1), 38-50.

Liebowitz, J., \& Chen, Y. (2001). Developing knowledge-sharing proficiencies. Knowledge Management Review, 3, 12-15.

Lin, H. F. (2007). Effects of extrinsic and intrinsic motivation on employee knowledge sharing intentions. Journal of Information Science, 33(2), 135-149.

Mura, M., Lettieri, E., Radaelli, G., \& Spiller, N. (2016). Behavioural operations in healthcare: a knowledge sharing perspective. International Journal of Operations \& Production Management, 36(10), 1222-1246.

Mura, M., Lettieri, E., Radaelli, G., \& Spiller, N. (2013). Promoting professionals' innovative behaviour through knowledge sharing: the moderating role of social capital. Journal of Knowledge Management, 17(4), 527-544.

Nguyễn, Đ. T., \& Nguyễn, T. M. T. (2009). Nghiên cưu khoa học trong quản trị kinh doanh. Thống kê.

Nonaka, I., \& Takeuchi, H. (1995). The knowledge-creating company: How Japanese companies create the dynamics of innovation. Oxford university press.

Oldenkamp, J. H. (2001, November). Limitations of managing knowledge sharing. In Proceedings of the Second European Conference on Knowledge Management, Bled, Slovenia (pp. 411-418).

Phung, V. D., Hawryszkiewycz, I., Chandran, D., \& Ha, B. M. (2017, December). Knowledge sharing and innovative work behaviour: A case study from Vietnam. In Australasian Conference on Information Systems.

Qammach, N. I. J. (2016). The mediating role of knowledge sharing on relationship between IT capability and IT support as predictors of innovation Performance: An Empirical Study on Mobile Companies in Iraq. Procedia Economics and Finance, 39, 562-570.

Radaelli, G., Lettieri, E., Mura, M., \& Spiller, N. (2014). Knowledge sharing and innovative work behaviour in healthcare: A micro-level investigation of direct and indirect effects. Creativity and Innovation Management, 23(4), 400-414.

Scott, S. G., \& Bruce, R. A. (1994). Determinants of innovative behavior: A path model of individual innovation in the workplace. Academy of Management Journal, 37(3), 580-607.

Tohidinia, Z., \& Mosakhani, M. (2010). Knowledge sharing behaviour and its predictors. Industrial Management \& Data Systems, 110(4), 611-631.

Turgut, E., \& Beğenirbaş, M. (2013). Çalışanların yenilikçi davranışları üzerinde sosyal sermaye ve yenilikçi iklimin rolü: Sağlık sektöründe bir araştırma. Kara Harp Okulu Bilim Dergisi, 23(2), 101-124.

Van Den Hooff, B., \& De Ridder, J. A. (2004). Knowledge sharing in context: the influence of organizational commitment, communication climate and CMC use on knowledge sharing. Journal of Knowledge Management, 8(6), 117-130.

Vithessonthi, C. (2008). Social interaction and knowledge sharing behaviors in multinational corporations. The Business Review, 10(2), 324-331.

Vorakulpipat, C., \& Rezgui, Y. (2008). An evolutionary and interpretive perspective to knowledge management. Journal of Knowledge Management, 12(3), 17-34.

Wang, S., \& Noe, R. A. (2010). Knowledge sharing: A review and directions for future research. Human resource Management Review, 20(2), 115-131.

Weggeman, M. C. D. P. (2000). Kennismanagement: de praktijk. Scriptum Management.

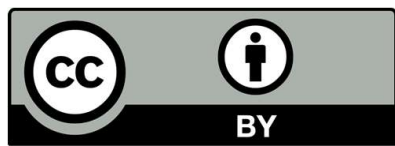

(C) 2020 by the authors; licensee Growing Science, Canada. This is an open access article distributed under the terms and conditions of the Creative Commons Attribution (CCBY) license (http://creativecommons.org/licenses/by/4.0/). 